\title{
Feed Forage and Nutrition Value at Altitudes During the Dry Season in West Java
}

\author{
Ana Rochana ${ }^{1}$, Nyimas Popi Indriani ${ }^{1}$, Budi Ayuningsih ${ }^{1}$, Iman Hernaman ${ }^{1}$, Tidi Dhalika ${ }^{1}$, Dedi Rahmat ${ }^{1}$, and \\ Sari Suryanah ${ }^{2}$

\begin{abstract}
${ }^{1}$ Faculty of Animal Husbandry, Padjadjaran University, Bandung, Indonesia.
${ }^{2}$ Faculty of Agriculture, University of Bandung Raya, Bandung, Indonesia

Corresponding author email: arochana2@gmail.com
\end{abstract}

\begin{abstract}
Field grass is a source of ruminant forage, especially for rural farmers in West Java in different altitudes. The aim of this study was to determine the potential of grass during the dry season including botanical composition analysis and chemical analysis of nutritional value. The study was conducted from September to November 2015 in survey method with multistage sampling. The parameters measured were botanical composition of the forage, biomass production of feed materials on fresh and dry matter, dry matter content, an inorganic matter including calcium and phosphorus, protein, crude fiber and nitrogen free extract. The results concluded for West Java in the dry season that the nutrient content of dry matter and $\mathrm{P}$ in lowlands, medium and highland was similar. Crude protein, NFE and TDN at high altitude had higher percentage compared to medium and lowland but crude fiber at high altitude was lower than lowland. $\mathrm{Ca}$ at high altitude had higher percentage compared to medium altitude.
\end{abstract}

Key words: Forage, ruminants, botanical composition, nutritional content, altitude

Abstrak. Rumput Lapangan merupakan sumber hijauan pakan ternak ruminansia, khususnya bagi peternak di pedesaan Jawa Barat diberbagai dataran (tinggi, sedang dan rendah). Tujuan dari penelitian ini adalah untuk mengetahui potensi rumput lapangan pada saat musim kemarau yang meliputi analisis komposisi botanis dan analisis kimia nilai nutrisi. Penelitian dilakukan dari bulan September sampai November 2015. Metode yang digunakan adalah metode survey, pengambilan sampel dilakukan secara bertahap (multistage sampling). Peubah yang diukur pada penelitian meliputi komposisi botanis hijauan pakan, produksi biomassa bahan pakan pada kondisi segar dan bahan kering, kandungan bahan kering, bahan anorganik meliputi kalsium dan pospor, protein, serat kasar, bahan ekstrak tanpa nitrogen. Hasil menyimpulkan untuk Jawa Barat pada musim kemarau bahwa nilai nutrisi bahan kering dan $\mathrm{P}$ di dataran rendah, menengah dan dataran tinggi adalah serupa. Protein kasar pada ketinggian tinggi memiliki persentase yang lebih tinggi dibandingkan dengan dataran sedang dan dataran rendah. BETN dan TDN di ketinggian rendah memiliki persentase yang lebih tinggi dibandingkan dengan dataran sedang dan dataran tinggi. Serat kasar pada ketinggian tinggi memiliki persentase yang lebih rendah dibandingkan dengan dataran rendah. Ca pada ketinggian tinggi memiliki persentase yang lebih tinggi dibandingkan dengan ketinggian sedang.

Kata Kunci: Hijauan pakan, ruminansia, komposisi botanis, kandungan nutrisi, ketinggian

\section{Introduction}

Grass was the main feed for sheep, either grazing or stabled. Sofyan (2003) states that the forage fodder used for ruminants is mostly grass, so grass plays crucial role in the provision of feed. In grazing systems, it is required to evaluate the forage quality to know the amounts of protein and energy supplied to sustain the livestock (Wen et al., 2013). A sheep needs forage about 10 percent of body weight (Devendra and McLeroy, 1982). The grass-based nature of production can be divided into two groups: 1) non-cultivated grass like a field grass, natural grasslands, shrubs and trees; 2) cultivated grass, either permanently or temporarily. A pasture typically includes various of grasses and legumes, whereas cultivated pasture consists of only one or few species of grasses or legumes. Fodder forage nutrient composition varies depending on several things namely plant species, plant age, climate and fertilization (Jayanegara, 2012). 
Field grass can be fed to livestock in large quantities and can be grown on land varying conditions (Lopez, 1992). According to Susilawati (2014), grass or wild plants as green fodder can be obtained and breeded from various sources for example 1) Weeds on agricultural lands. 2) plants that grow wild in the plantations lands (rubber, banana, oil palm). 3) Forage derived from forestry regions that grow in the shade of the trees. 4) Foliage of a tree that serves as a living fence, usually in limited land ownership. 5) The forage had low quality, which cannot provide sufficient nutrients to support productivity, because the nutrients contained in the field grass is not meet their physiological needs nutrients, especially protein (Purbowati et al., 2005).

Legumes have the potential to reduce global warming of the farm system by reducing emissions of methane and nitrous oxide pasture and forage production (Payraud et al., 2009). However legumes recommended maximum of $30 \%$ of the total ration.

Grasses and legumes as raw material are needed in large quantities and strongly influenced by the availability of local agricultural systems (Indriani et al., 2015). Botanical composition is the figure used to determine the assessment of the quality of the pasture or meadow grazing that can affect livestock production (Susetyo, 1980). Results of growth can be measured simply by the weight gain whole plants or parts of plants including parts harvested and other parameters (Sitompul and Guritno, 1995). Growth can also be demonstrated by the size of the leaf, fresh weight and dry weight of plants that include roots, stems, leaves and fruit, cell number and content of certain chemical compounds, such as nucleic acids, dissolved nitrogen, lipids and carbohydrates in the tissues (Noggle and Fritz, 1983).

Internal factor or genetic factors are factors the plant itself, the nature of the material contained in the plant/seed used. The seeds can be derived from the seeds, stems/branches, roots, leaves, roots and so on. Judging from the origin of planting material, plants can be propagated by generative (with seeds) and by vegetative (other than seed). While environmental factors among others influenced by: water, land, sunlight, temperatures and humidity.

Water is part of every cell, the amount varies depending on the network. Water is a solvent system of cells and provide a medium for the transport in the soil. Water can maintain turgor necessary in complexity transpiration and growth in plants. Water is also required as a nutrient for the formation of new compounds (Harjadi, 1979). Water is an essential compounds for plants, in most cells and tissues of plants a high level of water quantity could reach $80 \%$ of the fresh weight. Jumin (1992) describes some of the functions of water for plants is an important element in the formation of protoplasm, as a solvent and transport medium of nutrients, play a role in the process of photosynthesis and respiration, as the guardian of turgor of plant cells and regulatory mechanisms of movement in plants.

According to Soepardi (1983), poor soil aeration could lead to a shortage of $\mathrm{O} 2$, disruption of activities such as nitrification bacteria, nitrogen engagement, and amonification. Excess water will also eliminate nutrients due to leaching. Water available is water that exists between water field capacity and wilting coefficient. Irrigation research shows that for optimum growth of plants, water that should be added is $50 \%$ to $85 \%$ of available water.

Water that exceeds field capacity (excess water) is less useful for plants because it will cause poor aeration so the soil will be lack of oxygen needed by plants and nitrogen-fixing bacteria in the soil (De Datta, 1981).

Light intensity is the amount of energy received by the earth at a time and specific areas. The amount of energy received by the 
earth depends on the quality and the long period of irradiation. Harjadi (1979) said that high light intensity affects the water content of leaves and leaves a deficit of water that will be followed by the closing of stomata so it will reduce the rate of photosynthesis. Light is part of the sun's radiation spectrum and is a component of the physical environment that is essential for all living things, especially plants, which directly or indirectly affect the growth and development of plants (Jumin, 1992). According to Sitompul and Guritno (1995), plant growth depends on the intensity, quality, duration (perioditas) and direction of light. The light energy is responsible for the photosynthetic activity and the amount of binding of the $\mathrm{N}$ through a chemical reaction.

The temperature range for plants growth generally ranges between $15^{\circ}-40^{\circ} \mathrm{C}$. The temperature of a place is determined by the altitude (height) and latitude (latitude). High atmospheric temperature will accelerate plant growth and respiration but also can harm plants when the moisture is inadequate causing miscarriage flowers, young fruit and leaves. The hot air and dry winds will increase further crop damage. Soil temperature can also affect the absorption of water by plants (Harjadi, 1979).

Transpiration of plants is closely related to the absorption of nutrients from the soil. If the rapid transpiration, absorption of nutrients will also be faster. However, if the humidity is high causing transpiration to be slow, so the absorption of nutrients will also be slow. High humidity can stimulate growth of mold, fungi, bacteria, which can harm plants (Harjadi, 1979).

\section{Materials and Method}

The study was conducted by survey method, sampling was done in stages (multistage sampling). The first phase determines the district using purposive sampling considerations: the potential of biomass feed, planting area and production capacity, density of livestock. Land used basic data was taken from statistical data (secondary data) available for West Java. The second stage was determining areas of selected districts. The third stage was determining sample for primary data collection. The primary data of biomass production and nutritional value of feed ingredients were obtained through field sampling and chemical analysis of samples of feed ingredients were taken at the time of the survey.

\section{Data collection}

Stages of field data collection (primary data) included the measurement of biomass production that consisted of cutting, weighing, and drying for feed ingredients including classification of dry forage and hay. To measure the biomass production of both classes of feed used quadran with size of $0.5 \mathrm{~m}^{2}$. Cutting class of feed is done with cutting tools between 2.5 $\mathrm{cm}$ for small sizes up to $10 \mathrm{~cm}$ above the ground for larger forage and hay crop. Immediately after the cut, the feed material is weighed to measure the fresh weight. After weighing, samples of feed ingredients were put into a labelled paper bag, the weight was measured and gradually dried to water-free, then a chemical analysis was performed to determine nutrient content.

\section{Measured variables}

The measured parameters in the first year of study covered the botanical composition forage, biomass production of feed material on the condition of fresh and dry matter, content of dry matter, inorganic matter including ash, calcium and phosphorus, crude protein, crude fiber, extract materials without nitrogen and total digestible nutrients.

\section{Data analysis}

The data obtained were tabulated by cluster area previously set and presented by descriptive analysis. Estimation of biomass production using population parameter estimation and comparison of potential feed for each cluster were subject to ANOVA. 


\section{Results and Discussion}

The activities farmers carried out were:

1. In highland, farmers utilized legumes tree in the forest area around the buffer zone. Only in extreme conditions did dairy farmer use agricultural waste rice straw.

2. In the middleland there was a migrating stock of natural forage, especially in the area of forestry and plantations, as well as the utilization of rice straw, rice ratoon and even vegetable wastes.

3. At lowland areas there was a vast utilization of rice straw to support the availability of feed, in addition to the activities of rice straw and rice ratoon fermentation thas was accomplished in part of a group of farmers.

\section{Botanical composition}

Botanical composition measurement results on the site study in West Java used as forage areas is presented in Table 1.

The sampling was taken during dry season thus representing botanical composition during the season. Based on the percentage botanical composition, the percentage of the grass was still above $60 \%$, so it can be categorized still have a sufficient level of palatability and feed quantity, but for a legume it was very little even for some places it is not found, whereas the level of percentage of weeds is very high.

On highland, the samples taken at an altitude of $1270 \mathrm{~m}$ above sea level, all kinds of botanical composition were found, but high enough level of weeds as well. In the upland areas were various types of grasses such as Axonopus (Axonopus compressus), african (Cynodon plectostachyus), carulang (Eleusina indica), kakawatan (Cynodon dectylon) and elephant grass (Pennisetum purpureum). The dominant legume and legume tree was sentrosema (Centrosema pubescen) and kaliandra (Calliandra calothyrsus), respectively. Weeds found were sadagori (Sida rhombifolia L), putrimlu (Mimosa pudica), kirinyuh (Chromolaena odorata) and balakacida (Milkania cordata). The grass on the medium altitude was very dominating with botanical composition of 60 to $70.2 \%$, and weeds are found in the medium altitude. Grass found in this area are kakawatan (Cynodon dectylon), carulang (Eleusina indica), african (Cynodon plectostachyus), talisaid (Commelina benghalensis) and elephant grass (Pennisetum purpureum). Weeds found are babadotan (Ageratum conyzoides), sadagori (Sida rhombifolia L), galinggang (Cassia quaderialata) and nanangkaan (Euphorbia hirta).

Table 1. Composition of feed botanic forage at different areas in West Java

\begin{tabular}{|c|c|c|c|}
\hline \multirow{2}{*}{ Altitude and Location } & \multicolumn{3}{|c|}{ Botanical Composition (\%) } \\
\hline & Grass & Legume & Weed \\
\hline \multicolumn{4}{|l|}{ Lowland } \\
\hline Gunung Kerta (Karawang) & 65.82 & 00.00 & 25.48 \\
\hline Klari (Karawang) & 70.20 & 18.08 & 11.72 \\
\hline \multicolumn{4}{|l|}{ Medium altitude } \\
\hline Rancabago (Garut) & 70.20 & 00.00 & 21.10 \\
\hline Mekar Jaya (Garut) & 65.52 & 08.70 & 25.78 \\
\hline Cisompet (Garut) & 60.38 & 26.35 & 13.27 \\
\hline Kertamukti (Tasikmalaya) & 70.20 & 00.00 & 21.10 \\
\hline \multicolumn{4}{|l|}{ Highland } \\
\hline Cikandang (Garut) & 67.72 & 12.66 & 24.62 \\
\hline Gombong (Tasikmalaya) & 60.38 & 10.55 & 20.37 \\
\hline
\end{tabular}


In the medium altitude area in the Cisompet village of, the samples were took from the area of oil palm plantations shows that legume grown in the plantation area. It shows that the shade still provided an opportunity to legume to grow. The legume available were sentrosema (Centrsema pubescen) and kalopo (Callopogonium muconoides). Grass found in the area was Axonopus (Axonopus compressus).

\section{Feed forage production}

The following forage production data for each plains in various areas in West Java are presented in Table 2.

Table 2 shows that the productivity of forage in the dry season is so low that it is difficult to support the existing population in the area. In lowland areas and medium altitude forage production of the land has a low value for forage dry matter, but on the high altitude, forage productivity in the dry season is relatively available.

Forage nutrient content at the end of the dry season can be seen in Table 3. Based on data in Table 3, nutrient content percentage of dry matter and $P$ in lowlands, medium and highland is not significantly different.

Crude protein at high altitude is significantly higher than the medium and lowland. The NFE and TDN at low altitude are significantly higher than medium and highland. Crude fiber at high altitude is significantly different lower compared to lowland. Ca percentage at high altitude is significantly higher than the medium.

Table 2. Feed Forage Productivity in Various Plain in West Java

\begin{tabular}{lcc}
\hline \multirow{2}{*}{ Altitude and Location } & \multicolumn{2}{c}{ Forage productivity/quadran (g) } \\
\cline { 2 - 3 } & Freshweight & Dryweight \\
\hline Lowland & 105.8 & 32.70 \\
$\quad$ Gintung Kerta (Karawang) & 99.90 & 40.00 \\
$\quad$ Klari (Karawang) & & \\
Medium altitude & 65.40 & 30.40 \\
$\quad$ Ranca bango (Garut) & 196.5 & 40.70 \\
Mekar Jaya (Garut) & 69.10 & 29.40 \\
Cisompet (Garut) & 113.3 & 41.30 \\
Kertamukti (Tasikmalaya) & & \\
Highland & 126.5 & 43.80 \\
$\quad$ Cikandang (Garut) & 100.2 & 39.50 \\
Gombong (Tasikmalaya) & & \\
\hline
\end{tabular}

Table 3. Nutrient Content Feed Forage at Different Plain in West Java

\begin{tabular}{lccccccc}
\hline \multirow{2}{*}{ Altitude } & \multicolumn{7}{c}{ Nutrient (\% Dry Matter) } \\
\cline { 2 - 8 } & DM & CP & CF & Ca & P & NFE & TDN \\
\hline Lowland & $34.33^{\mathrm{a}}$ & $8.41^{\mathrm{a}}$ & $24.31^{\mathrm{b}}$ & $0.36^{\mathrm{ab}}$ & $0.197^{\mathrm{a}}$ & $55.67^{\mathrm{c}}$ & $59.03^{\mathrm{b}}$ \\
Medium altitude & $35.29^{\mathrm{a}}$ & $11.35^{\mathrm{b}}$ & $23.31^{\mathrm{ab}}$ & $0.31^{\mathrm{a}}$ & $0.217^{\mathrm{a}}$ & $51.71^{\mathrm{b}}$ & $54.01^{\mathrm{a}}$ \\
Highland & $36.08^{\mathrm{a}}$ & $16.29^{\mathrm{c}}$ & $22.06^{\mathrm{a}}$ & $0.39^{\mathrm{b}}$ & $0.194^{\mathrm{a}}$ & $48.40^{\mathrm{a}}$ & $54.36^{\mathrm{a}}$ \\
\hline
\end{tabular}

DM: Dry matter, CP: Crude protein, CF: Crudefiber, NFE: Nitrogen Free Extract, TDN: Total Digestible Nutrient . The value in the column followed by different letters showed significant differences according to Duncan test at $5 \%$ level 


\section{Results and Discussion}

The activities carried out in the early stages of this research was completed nearly three months and reached the intended target of the proposed initiative. This activity included the analysis of botanical composition in three districts in the sample and then analyzed the content of nutrients. September to October was dry season and the relatively long time of high intensity of solar radiation. These conditions encourage the availability of forage fodder resulting in a very limited carrying capacity of the region, especially forage deficient to support ruminants, especially sheep, in the surveyed area. The condition also illustrates the productivity of forage availability throughout the year, especially during the dry season and the result can be categorized as very low production.

\section{Botanical composition}

From Table 1 it shows that the weed increased during the dry season due to its considerably high adaptability to extreme climatic conditions and environments. Low legumes conditions caused low legumes in the area because of inability to compete with existing weeds.

Ecosystem pasture with legumes and other plant species can increase productivity, resistance to weather disturbances and animal. Legume plants and $\mathrm{N}$-bound bacteria could improve the content of nitrogen in the soil and the plants so the protein in the plant increased the productivity and quality of forage for livestock (Bisinger and Russell, 2013).

Field observation revealed that drought resulted in a very limited number of natural grass, so agricultural wastes especially rice straw is very widely used in various areas to meet the needs of feed. Most farmers also mobilized to areas that still had forages such as forestry and plantation areas to take forage.

\section{Feed Forage Production}

According to Fitria et al. (2013) the component of climate change in the dry season including very low rainfall, and relatively high temperatures that ultimate extreme climate can reduce the population of certain plants. In the medium altitude area in Garut, namely Rancabango and Cisompet village showed a low value of the dry weights. It was because samples were taken under the shade of cassava and palm oil. Many plants feed were shaded, while the forage crop need high solar radiation to grow because the grasses are $\mathrm{C} 4$ plants. The production of dry matter was low. This is in accordance with Lambers et al. (2008) that the grass plants are called C4 plants, can flourish in an open ecosystem with a high temperature.

In lowland areas, samples were taken from around the moor of rice cultivation with little shade but too much exposure to dryness resulted in relatively less forage production. In highland areas such as in Cikajang Garut has an altitude of about $1270 \mathrm{~m}$ above sea level, then the cold temperatures reduce evaporation, especially in the dry season. This causes the plants to survive and forage production was higher than in lowlands and medium altitude.

Phosphorus is very closely linked to the production plant and is one which affects the dry matter. This is proofed from the content of dry matter and phosphorus are similar and not significantly different in all three heights (lowland, medium and high). According to Habibzadeh (2015) Phosphorus is a mineral as vital macronutrient for growth, crop production, plant nucleic acid structural components, bio-membrane, cell division and tissue development and energy metabolism.

Crude protein is a nutrient essential for life and growth of sheep. Crude protein fulfilled for the sheep, and then the sheep can functions the process of decomposition of coarse fiber derived from forage and the availability of amino acids for the sheep. The higher altitude, 
the lower the temperature thus the lower solar radiation. Highland in Cikandang village (Garut) and Gombong village (Tasikmalaya District) have higher protein and significantly different than in the medium altitude and in lowlands. Low radiation in highlands and many legumes can produce high crude protein. According to Guenni, et al., (2008) grass need solar radiation in full for growth and development and it is in lowlands, but the grass in highlands showed an increase in crude protein with the decrease in sunlight intensity. According to Mishra et al. (2013) The quality of fiel grass improved at the lower light intencity as indicated by higher accumulation of protein. Crude protein content in leaf and stem was higher at the lower light intencity. The protein content was more in leaves than the protein in stem. The crude protein is directly related with the avai lable nitrogen content in the leaves and stem and it is assumed th at under high shading environment the inorganic nitrogen in the form of nitrate was more, which might be due to slow process of nitrogen assimilation.

The rumen is the digestive tract of sheep used as a fermentation that can solve the high coarse fibrous feed and low quality. Crude fiber content varies inversely with Crude protein, it can be seen at low and highland shown in Table 3. Plants feed on lowland get full sun radiation so has a greater fiber content which is forming energy for plants and crude protein decreased when compared to highland. De Freitas et al., (2012) said that the fiber content in the Tanzania grass forage was low, which emphasizes the advantage of the management based on lower light for the higher nutritive value production of forage.

According to Mc Donald et al. (2010) the control of rumen fermentation arises from the need supplies of energy and protein to the microorganisms. The bacteria need a supply of energy to synthesise their cell proteins from degraded food proteins, and their energy sources
The balance of calcium and phosphorus is required for the maintenance of bone tissue, muscle contraction, energy metabolism, facilitate digestion and absorption of nutrients as well as renewing cells that die for sheep growing. Calcium ( $\mathrm{Ca}$ ) and phosphorus $(\mathrm{P})$ are the most requred minerals by animal. Calcium and phosphorous are most often added to ruminant diets. Theya are required in the teeth and bones, but calcium is also required in milk. In addition, $\mathrm{Ca}$ is required for the clotting of blood and the contraction of muscles. Soetan et al. (2010) stated ruminant need large amounts of calcium to construct and maintain the bone and normal function of nerves and muscles. Phosphorus is an important component of adenosine triphosphate (ATP) and nucleic acid and is essential for acid-base balance, bone and tooth formation.

$\mathrm{Ca}$ and $\mathrm{P}$ minerals are needed by livestock, and also very important for forage crops even in small amounts but the crucial role is as a catalyst or a substance that can accelerate the chemical compounds in the plants. Waraich et al. (2011) informed that Ca has a role to play in freeze injury tolerance and minimize detrimental effects of drought in crop plants by improving Ca. Calcium has role in the maintenance of cell structure. Ca activates the plasma membrane enzyme ATPase which pumps back the nutrients lost during cell membrane damage due to Ca deficiency and recover the plant from injury. Calcium also has a role as calmodulin and controls the plant metabolic activities and enhances the plant growth under drought condition. Phosphorus maintains the cell turgidity by maintaining the high leaf water potential then increases the stomatal conductance and increases the photosynthetic rate under drought.

Hartadi et al. (2005) states that the value of TDN influenced by Crude Protein, crude fiber, fat Crude and NFE. High results of the chemical composition will rise TDN value of forage material and vice versa if the chemical 
composition of the material is lower it will lower the value of TDN. NFE levels obtained from the reduction of the moisture content, ash, crude protein, crude fat and crude fiber so that its value is affected by the nutrient content of forage. The higher levels of TDN are noticeably reached when the legume is intercropped with the grasses, Moreira et al. (2015). The supplements of high TDN levels linearly improved the microbial efficiency of finishing pasture-grazed beef cattle, Koscheck et al. (2013).

\section{Conclusions}

It can be concluded for West Java in the dry season that the nutrient content of dry matter and $P$ in lowlands, medium and highland are similar. Crude protein at high altitude had higher percentage compared to medium and lowland. NFE and TDN at low altitude had higher percentage compared to medium and highland. Crude fiber at high altitude had lower percentage compared to lowland. The $\mathrm{Ca}$ at high altitude had higher percentage compared to medium altitude

\section{References}

Bisinger JJ and JR Russel. 2013. Enhancing Botanical Composition and Wildlife Habitat of Pastures in South Central lowa through Soil Disturbance by Mob-Grazing of Beef Sheep. Animal Industry Report. lowa State University Animal Industry Report. $p p .1-6$.

De Freitas FP, DM da Fonseca, TG dos Santos Braz, JA Martuscello and MER Santos. 2012. Forage yield and nutritive value of Tanzania grass under nitrogen supplies and plant densities. R. Bras. Zootec. 41(4):864-872,

De Datta. 1981. Pinciples and Practice of rice Production. John Willey and Sons, Inc. New York.

Devendra C and GB McLeroy. 1982. Sheep Breeds, In : Goat and Sheep Production in The Tropic. ELBS. Longman Goup Ltd. England. 155.

Fitria R, K Stein and A Lindner. 2013. Climate change impacts on biodiversity- the setting of a lingering global crisis. Diversity 5: 114-123. DOI: 10.3390 / d5010114
Guenni O, S Seiter and R Figueroa. 2008. Growth respons of three Brachiaria species to light intensity and nitrogen supply. Trop. Grasslands. 42:75-87.

Habibzadeh Y. 2015. Effect of phosphorus level on dry matter production and root traits of chickpea plants in presence or absence of arbuscular mycorrhizal fungi. Agric.Sci.Food.Technol. 1(1):16.

Harjadi SS. 1979. Introduction to Agronomy. PT. Gramedia. Jakarta.

Hartadi H, S Resohadiprodjo dan AD Tillman. 2005. Feed Composition Table for Indonesia. Gadjah Mada Press. Fifth edition. Yogyakarta.

lin-Susilawati, L Khairani and R Zamhir I. 2014. Feed Forage Types in West Java. Animal Husbandry and Official agency west Java.

Indriani NP, Y Yuwariah, A Rochana and H Djuned. 2015. Effect of Intercropping between corn (Zea mays) and peanut (Arachis hypogaea) with Arbuscular Mycorrhizal Fungi (AMF) on the yield and forages mineral content. Pakistan Journal of Nutrition. 14(6):362-365.

Jayanegara A. 2012. Animal Feed Materials. Laboratory of Animal Feed Technology. Animal Husbandry IPB (Bogor Agriculture Institute). Bogor. Through https://anuragaja.staff.ipb.ac.id /files/2012/04/Buku-PBMT.pdf (Accessed in 11 November 2015, at 21.00 o'clock WIB).

Jumin HB. 1992. Plants Physiological Ecology Approach. Rajawali Press. Jakarta.

Koscheck JFW, J T Zervoudakis, L K H Zervoudakis, L da S Cabral, AA de Oliveira, JMB Benatti, DM G. de Carvalho and RP da Silva, 2013. Total digestible nutrient levels in supplements for finishing steers in therainy season: nutritional characteristics and microbial efficiency. R. Bras. Zootec. 42(11):.798-805

Lambers H, TL Pons and FS Chapin III. 2008. Plant Physiological Ecology. 2nd. Springer ScienceBussiness Media LLC. New York.USA.pp.73-75. DOI: 10.1007 / 978-0-387-7834-3

Lubis D A. 1963. Animal Feed Science. Second edition. PT Yayasan Pembangunan. Jakarta. 21 22.

Mc Donald P, RA Edwards, JFD Greenhalgh, CA Morgan, LA Sinclair and RG Wilkinson. 2010. Animal Nutrition. Seventh Edition. Prentice-Hall. Harlow. England.

Mishra AK, HS Tiwari and RK Bhatt. 2010. Growth, biomass production and photosynthesis of Cenchrus ciliaris L. Under Acacia tortilis (Forssk.) Hayne based silvopastoral systems in semi arid tropics. Journal of Environmental Biology. 31(6):987-993.

Moreira JFM, KAD Costa, ED Severiano, GA Simom, PS Epifanio, WS Crunivel and JC Bento. 2015. 
Production and bromatological composition of cultivars of Brachiaria brizantha and Campo Grande stylo monocropped and intercropped under different planting methods. African Journal of Agricultural Research. 10(5):317-327. DOI: 10.5897/AJAR2014.8822

Noggle G R and G J Fritz. 1983. Introductory Plant Physiology. 2nd ed. Prentice-Hall, Inc. New Jersey.

NRC. 1985. Nutrient Requirements of Sheep. National Academy Press. Washington. D.C.

Payraud J L, A Le Gall and A Luscher. 2009. Potential food production from forage legume-basedsystem in Europe : an overview. Irish Journal of Agricultural and Food Research 48:115-135.

Purbowati E. 2007. Study of Fattening Local Lamb Carcass with Complete Feed from Rice Straw and Concentrate on Different Weights Cut. Graduate Program Gadjah Mada University. Yogyakarta. (Doctoral Thesis Animal Science).

Soepardi G. 1983. Soil Nature and Characteristics. Department of Soil Science, Faculty of Agriculture. Bogor Agricultural Institute. Bogor.

Sitompul SM and B Guritno. 1995. Plant Growth Analysis. Universitas Gadjah Mada Press. Yogyakarta.
Soetan KO, CO Olaiya and OE Oyewole .2010. The importance of mineral elements for humans, domestic animals and plants: A review. Afr.J. Food Sci. Vol. 4(5):200-222

Sofyan I. 2003. Business Development Study of Elephant Grass for Provision of Feed on Beef Cattle Fattening at PD. Gembala Garut regency, West Java. Agribusiness Management Program. Faculty of Agriculture. IPB

Susetyo. 1980. Pastures. Departement of Animal Feed Science. Animal Husbandry Faculty. Bogor Agricultural Institute (IPB), Bogor.

Waraich EA, A Rashid, Saifullah, MY Ashraf and Ehsanullah. 2011. Role of mineral nutrition in alleviation of drought stress in plants. Australian Journal of Crop Science. 5(6):764-777

Wen L, SK Dong, YY Li, C Pulver, XY Li, JJ Shi, YL Wang, YS Ma and DM Liu. 2013. Variation of botanical composition, forage production and nutrient values along a grassland degradation gradient in the alpine region of Qinghai-Tibet Plateau. International Journal of Experimental Botany. 82:45-54. 